\author{
М.Ф. Пічугін ${ }^{1}$, Я.М. Кожушко ${ }^{1}$ Д.А. Іщенко ${ }^{2}$, В.А. Кирилюк ${ }^{2}$, С.Д. Іщенко ${ }^{3}$, О.В. Беспалько ${ }^{1}$ \\ ${ }^{1}$ Харківський національний університет Повітряних Сил ім. І. Кожедуба, Харків \\ ${ }^{2}$ Житомирський військовий інститут ім. С.П. Корольова, Житомир \\ ${ }^{3}$ Військова частина А 0515, Київ
}

\title{
УДОСКОНАЛЕНИЙ ПІДХІД ДО ОЦІНЮВАННЯ НОСІЇВ СПРОМОЖНОСТЕЙ РАДІОЕЛЕКТРОННОЇ БОРОТЬБИ ЗА СКЛАДОВОЮ ВАРТОСТІ ЖИТТЄВОГО ЦИКЛУ
}

\begin{abstract}
У статті розглядаються питання, пов'язані з розробленням елементів науково-методичного апарату оиінювання військ (сил) щодо оиінювання носїв спроможностей радіоелектронної боротьби за складовою вартості життєвого ичиклу. Проведений аналіз літератури за даною тематикою. Представлений підхід до вдосконалення науково-методичного апарату оиінювання носіїв спроможностей формувань сил та засобів супровідної підтримки шляхом розроблення підходу до оцінювання носіїв спроможностей радіоелектронної боротьби за складової вартості їх життєвого циику в операиіях (бойових діях).
\end{abstract}

Ключові слова: оцінювання, подавлення, показник, радіоелектронна боротьба, спроможність.

\section{Вступ}

Постановка проблеми. Аналіз локальних конфліктів сучасності, досвіду антитерористичної операції (АТО) та операції об’єднаних сил (ООС) [1] показує, що у більшості випадків вогневе ураження противника та досягнення вогневої переваги залишається вирішальним фактором перемоги в бою. Але досягнення вогневої переваги потребує не тільки спроможностей “Застосування (ENGAGE - E)" бойових (основних) військових частин (підрозділів), але ще таких спроможностей, що їх забезпечують. Визначається особливе значення набуття спроможностей з радіоелектронної розвідки (РЕР) та радіоелектронної боротьби (РЕБ) [2-3], що відносяться відповідно до функціональної групи (інтегрованої категорії) спроможностей "Розвідка (INTELLIGENCE)" та “Захист та живучість (PROTECT)".

Необхідність оцінювання спроможностей військ (сил) обумовлює потребує визначення вартості тих формувань сил та засобів - носіїв спроможностей супровідної підтримки, що входять до їх складу та прогнозовано забезпечують не менш ніж потрібні підвищення ефективності бойових дій військ (сил) і зменшення ефективності дій противника.

В умовах ресурсних (людських, матеріальних, за часом) обмежень, прийняття грунтовних ефективних рішень на встановлення раціонального (для досягнення переваги) складу (бойового та чисельного) формування - носія спроможностей, потребує визначення прогнозованої вартості його життєвого циклу (ЖЦ). Особливо важливим є оцінювання вартості ЖЦ носія спроможностей на стадії "застосування”, оскільки саме на цій стадії визначають його ефективність за співвідношенням ефект/затрати. Визначення прогнозованої вартості військової частини-носія спроможностей супровідної підтримки (РЕР, РЕБ) на стадії “застосування”, особливо у фазі “виконання бойового (цільового) завдання" (ведення розвідки, радіоелектронне подавлення, електронна підтримка) є складним воєнно-науковим завданням, вирішення якого можливо за наявності відповідного науково-методичного апарату. Відсутність (недосконалість існуючої) системи показників оцінювання носіїв таких спроможностей, які враховують зв'язок вартісної складової та складової досягнення мети (ефекту) бойового застосування, обумовлюють проблему ефективного оборонного та оперативного планування застосування сил та засобів РЕР, РЕБ у бойових діях (операціях) військ (сил), в інтересах яких вони здійснюють бойове (оперативне) забезпечення.

Аналіз останніх досліджень та публікацій за визначеною тематикою показує, що для оцінювання носіїв спроможностей за складовою вартості їх життєвого циклу в операціях (бойових діях) можна використати положення, що мають місце у відомих роботах. Нормативним документом у предметній галузі $з$ оцінювання спроможностей слід вважати [4], відповідно до положень якого можна визначити, що базовими компонентами (складовими) спроможностей, які потребують оцінювання та врахування при плануванні, є: озброєння та військова техніка (ОВТ) РЕР (РЕБ); засади застосування сил та засо- 
бів; організаційні структури; системи відбору, навчання, підготовки та мотивації персоналу. У [5] надають загальні підходи до оцінювання вартості ЖЦ носія спроможностей. Використання [6-9] дозволяє грунтовно визначити у ЖЦ носія спроможностей стадію “застосування” у фазі “виконання бойового (цільового) завдання” для оцінювання їх вартості. У [10] наведено особливості планування на основі спроможностей та його впровадження у процес розвитку сил оборони України. Можливість дослідження питання оцінювання вартості військової частини-носія спроможностей за єдиним підходом до визначення потрібних категорій та розуміння термінів і визначень понять забезпечує [11] щодо планування в сфері воєнної безпеки 3 урахуванням стандартів, що прийняті в арміях держав-членів НАТО.

Більшість відомих авторам робіт присвячена питанням ЖЦ ОВТ, а не військових частин, на озброєння яких воно надходить, та оцінюванню його вартості. Підходи до оцінювання вартості життєвого циклу ОВТ досить широко висвітлені, зокрема, у [12-15]. У роботах, присвячених оцінюванню військових формувань [12-15], основним змістом залишається оцінювання їх вартості відповідно до існуючих інструкції (порядків) за видами забезпечення військових частин, установ та організацій Збройних Сил (3С) України, введених в дію наказами Міністерства оборони України.

Таким чином, відомі праці не надають повного науково-методичного апарату для оцінювання носіїв спроможностей таких показників, що поєднують вартісну складову з складовою досягнення мети бойового застосування, що не сприяє ефективному плануванню застосування сил та засобів РЕР, РЕБ в інтересах бойового (оперативного) забезпечення, дій військ (сил) у бойових епізодах відкритого збройного протиборства.

Крім того, аналіз змісту [16] набуття спроможності супровідної підтримки силами та засобами РЕР та РЕБ з використанням спеціальних методів та характерних до них способів радіо- та радіотехнічної розвідки (РР та РТР), радіоелектронного подавлення (РЕП), захисту (РЕЗт) та електронної підтримки має зв'язок із практичними завданнями військ (сил) щодо перспективного розвитку ЗС України [4].

У той же час в останніх проаналізованих роботах не висвітлено питання стосовно визначення підходу до оцінювання вартості військової частининосія спроможностей супровідної підтримки (РЕР, РЕБ) на стадії “застосування", особливо у фазі “виконання бойового (цільового) завдання” (ведення розвідки, радіоелектронне подавлення, електронна підтримка).

Відповідно, дослідження щодо розроблення удосконаленого підходу до оцінювання носіїв спроможностей радіоелектронної боротьби за складовою вартості ЖЦ в операціях (бойових діях) є важливим та актуальним науково-практичним завданням.

Таким чином, мета статті є вдосконалення науково-методичного апарату оцінювання носіїв спроможностей формувань сил та засобів супровідної підтримки шляхом розроблення підходу до оцінювання носіїв спроможностей за складової вартості ЖЦ в операціях (бойових діях).

\section{Виклад основного матеріалу}

Дослідження щодо розроблення підходу до оцінювання за складовою вартості життєвого циклу в операціях (бойових діях) носіїв спроможностей визначеної функціональної групи та мають на озброєнні відповідні системи, комплекси, зразки (далі - вироби) озброєння та військової техніки, потребує визначити умови його проведення.

Потребують визначення вихідні умови дослідження, допущення та обмеження, що не суперечать змісту положень оборонного планування, воєнного мистецтва щодо створення угруповань військ (сил) і формування військових частин - носіїв спроможностей, основ управління військами (силами) при підготовці та веденні дій за призначенням, відновлення порушеної боєздатності тощо.

По-перше, вважаємо за можливе та доцільне проведення досліджень на прикладі формування носія спроможностей з РЕБ. Можливість такого узагальненого для РЕР та РЕБ підходу на тактичному рівні грунтується певною подібністю завдань та методів, що реалізуються способами їх виконання, щодо добування інформації про джерела випромінювання (розвідки) у бойових порядках противника засобами безпосередньої РЕР та електронної підтримки формувань РЕБ і, відповідно, засобами РРТР формувань РЕР.

По-друге, потребує врахування той факт, що у фазі “виконання бойового (цільового) завдання" носій спроможностей 3 РЕБ повинен виконувати завдання РЕП, а отже його сили і засоби є першочерговими об'єктами розвідки та ураження противника. Виникнення потреби врахування у вартості життєвого циклу не тільки витрат, але й імовірних втрат, розширює проблему оцінювання носія спроможностей та надає більшої актуальності відповідних досліджень у типових бойових епізодах відкритого збройного протиборства.

По-третє, вважаємо, що в загальній системі планування операції (бойових дій) прийнято принципове рішення, щодо застосування сил та засобів формування - носія спроможностей, наприклад, функціональної групи захист та живучість (PROTECT) або розвідка (INTELLIGENCE), у типових бойових епізодах відкритого збройного протиборства.

По-четверте, формування (військова частина) носій спроможностей $\epsilon$ складною організаційно- 
технічної системою, що має організаційну (персонал) і технічну (виріб ОВТ) складову та такою, яка за ознакою ієрархічної побудови має у складі певні організаційно-технічні (організаційні) підсистеми (підрозділи) та сама є складовою надсистеми більш високого рівня формування (угруповання) військ (сил). Розвиток військової частини - носія спроможностей забезпечується розвитком виробу ОВТ протягом його ЖЦ, за моделлю, яка згідно з ДСТУ В-П 15.004 має шість стадій. Визначення життєвого циклу військової частини $є$ першим кроком у розробленні підходу до оцінювання вартості життєвого циклу військової частини - носія спроможностей $з$ РЕБ. Розвиток ОВТ передбачає, що виріб на “позавійськових” стадіях ЖЦ (“попередній задум”, “задум закупівлі”, “розроблення”, “виробництво”) набуває технічні (тактико-технічні) характеристики, що забезпечують можливість розвитку спроможностей за рахунок використання його за призначенням.

Функціонування зразка ОВТ у військовій частині здійснюється на відповідних стадіях ЖЦ виробу (“використання” та “підтримка”) та, у залежності від особливостей завдань бойової та повсякденної діяльності, визначає вартість ЖЦ виробу у військової частині. За аналогією зі стадіями та моделлю ЖЦ виробу ОВТ пропонується перелік таких стадій, що $\epsilon$ основними періодами ЖЦ військового формування, які реалізуються за відповідними моделями.

На рис. 1 пропонується, як найбільш прийнятна у дослідженні, рекурсивна [7] модель процесу ЖЦ військової частини, щодо обрання варіантів, прийняття рішення та планування застосування формування - носія спроможностей.

Найбільш раціональним критерієм прийняття рішення на виконання цільового завдання на стадії “застосування” життєвого циклу ВЧ РЕБ є критерій “якість-час-вартість”. Сутність цього критерію полягає в тому, що варіант застосування зразків техніки підрозділами РЕБ повинний вважатися ефективним лише в тому випадку, коли “внесок” цього зразка в збиток, що задається противнику, або відвернений собі збиток був не тільки тактично, але й економічно виправданий.

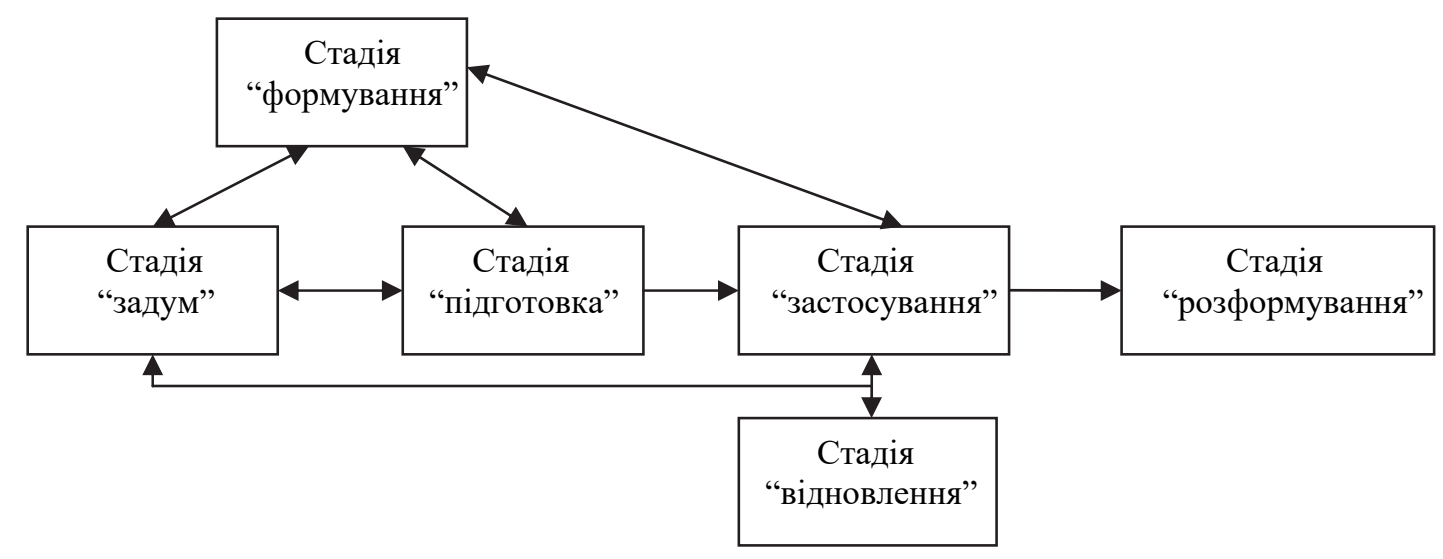

Рис. 1. Рекурсивна модель процесу ЖЦ військової частини (з різним порядком проходження стадій)

Джерело: розроблено авторами.

Досвід бойових дій в ході АТО та ООС підтверджує думки військових фахівців та дослідників про постійне зростання ролі радіоелектронної боротьби (РЕБ). Складовою забезпечення зростання РЕБ $\epsilon$ вдосконалення іiі форм і способів, що визначаються кількісним і якісним складом сил і засобів, які їх реалізують у визначеному, відповідно до бойового завдання, плану застосування.

Планування є деталізацією рішення на застосування військ (сил), що здійснюється у нормативно встановленому порядку роботи органів управління. Елементи роботи органів військового управління щодо планування, незалежно від їх належності до видів ЗС родів військ щодо організації РЕБ, багато у чому однакові. Системоутворюючим елементом у такій роботі, щодо планування застосування сил i засобів РЕБ, є оцінювання радіоелектронної обстановки та викриття побудови системи управління (розвідки) противника 3 метою встановлення місця розташування, якісних та кількісних характеристик радіоелектронних об'єктів і РЕЗ противника для визначення - цілей РЕП, відповідно до змісту бойового завдання військової частини - носія спроможностей з РЕБ. Такі дії проводяться за даними розвідки, як правило РР та РТР та безпосередньої РЕР, в умовах певної невизначеності.

Відомості про противника та інші умови та фактори обстановки, яких не вистачає, ідентифікують відповідно типових бойових епізодів (ТБЕ). ТБЕ формують у відповідності з відомими, за наявним досвідом дій противника, об'єктами та джерелами розвідки (РЕР) та його РЕЗ - цілями РЕП. 
На основі визначеного у такий спосіб положення, характеристик, імовірного характеру функціонування радіоелектронних об'єктів і засобів противника - цілей РЕП, визначають формування сил та засобів РЕБ, спроможності яких забезпечують виконання завдань військами (силами). Аналіз противника при формуванні ТБЕ базується на зіставленні наявного фактичного матеріалу та логіки уявлення органу управління про об'єкт оцінювання.

Для проведення оцінювання ефективності рішень, що приймаються у теорії та практиці як військового мистецтва, так і у військово-технічної галузі, потрібно правильне визначення сукупності факторів і умов як природного, так і штучного походження, в яких результати цих рішень будуть реалізовуватися силами та засобами військових формувань і угруповань військ. Можливість реалізації таких рішень забезпечується відповідними до завдань спроможностями. Крім того, безліч та різноманіття факторів і умов, ступінь їх впливу на адекватність рішень, що приймаються та реалізуються, вимагають та забезпечують доцільність та можливість правильного визначення припущень та обмежень, що не змінюють загального оперативно-тактичного та військово-технічного змісту завдання, щодо якого приймається рішення.

У практиці військового мистецтва ця вимога реалізується в ході підготовки бойового застосування військ та його матеріально-технічного забезпечення після з'ясування бойового завдання при оцінюванні обстановки щодо противника, своїх військ, умов, з врахуванням фактору часу, при постійному їх уточненні як при плануванні, так і в ході виконання завдань за призначенням та їх всебічному забезпеченні. В залежності від оперативно-тактичного рівня ланки органу управління, на який покладені завдання планування застосування військ, ступінь деталізації факторів і умов, що оцінюються, а також припущення та обмеження змінюються.

При проведенні досліджень у воєнній та військово-технічній галузях, щодо розвитку форм і способів застосування військ та перспективних засобів збройної боротьби, формулювання майбутніх завдань військ, оцінювання факторів і умов здійснюється шляхом застосування методів прогнозування.

У роботі [18] авторами розроблено та представлено підхід до оцінювання носіїв спроможностей РЕБ, необхідних для виконання завдань радіоелектронного подавлення в операціях (бойових діях). Використання запропонованих алгоритму та методики аналізу та оцінювання спроможностей дозволяє органам військового управління отримувати відповідні оцінки, потрібні для визначення сил і засобів, необхідних для виконання завдань РЕБ в операціях (бойових діях).

Приклад визначення сил і засобів, необхідних для виконання завдань РЕБ у тактичному бойовому епізоді (ТБЕ). Основним змістом завдання носія спроможностей з РЕБ є: у смузі відповідальності механізованої бригади здійснювати РЕП радіоелектронних об'єктів і засобів 3 метою дезорганізації управління формування військ (сил) противника та прикриття від ударів розвідувально-ударних БпАК бойових порядків (позиції) військ і військових об'єктів.

Для визначення сил і засобів, необхідних для виконання завдань радіоелектронної боротьби у ТБЕ виконують наступне.

1) Аналіз завдання умов та факторів загальної оперативної (тактичної) обстановки та радіоелектронної обстановки.

визначення кількості основних цілей РЕП: радіомереж (радіоліній) зв'язку формування військ (сил) противника: короткохвильового (КХ) - $N_{K X}$; ультракороткохвильового (УКХ) $-N_{У K X}$; транкінгового (Т) - $N_{T}$;

визначення потрібного ступеня дезорганізації управління противника, якого слід досягти у визначеному ТБЕ операції (бойових діях) - $K$;

визначення складу сил та засобів носія спроможностей з РЕП - військової частини РЕБ:

$N_{\text {Рот }}$; у кожної по $N_{\text {Взводів }}$, у кожному по

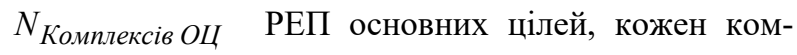

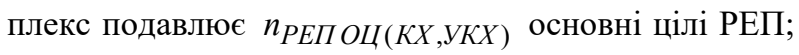
$3 N_{\text {Взводів окремих }}$, у кожному по $N_{\text {Комплексів } С Ц}$ РЕП спеціальних цілей, кожен комплекс подавлює

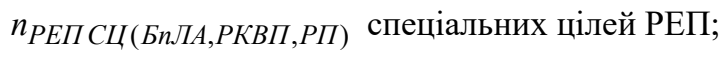

визначення умов: смуга відповідальності за фронтом - $L_{б р}$ км; дальність дії комплексу РЕБ 3

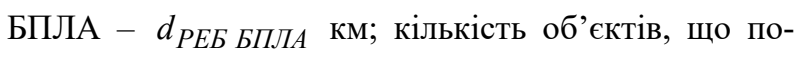
требують прикриття від БПЛА - $N_{\text {РЕБ БПЛА }}$

2) Визначення (прогнозування) основних і спеціальних (неосновних) цілей РЕП різного базування:

визначення кількості радіомереж (радіоліній) зв'язку противника, які будуть знищені засобами вогневого ураження: $\mathrm{KX}-N_{K X ~ в У} ; \mathrm{УКX} \mathrm{-}$ $N_{\text {УKX BУ }} ; \mathrm{T}-N_{T B Y} ;$

визначення кількості радіомереж (радіоліній) зв'язку противника, які слід подавити засобами РЕП: $\quad \mathrm{KX}$ радіозв'язку

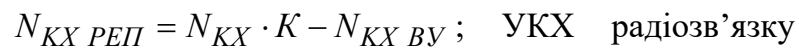

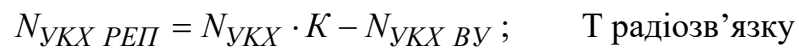
$N_{T \text { РЕП }}=N_{T} \cdot K-N_{T B Y} 1$.

3) Визначення потреб у основних і спеціальних (неосновних) засобах РЕП - спроможностях з РЕП визначеної кількості цілей противника різного базування: 
розрахунок потреби у засобах РЕП для реалізації спроможностей з РЕП:

кількість необхідних засобів РЕП КХ (УКХ, Т)

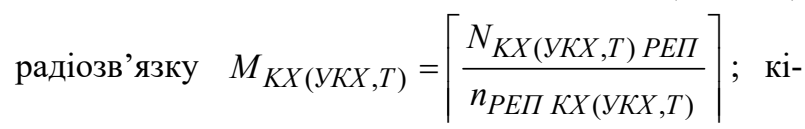
лькість необхідних засобів РЕБ 3 БПЛА $M_{\text {РЕБ БПЛА }}=\left\lceil\frac{L_{\text {бр }}}{2 d_{\text {РЕБ БПЛА }}}\right\rceil+M_{B O} ;$

розрахунок необхідних сил для реалізації спроможностей з РЕП:

кількість необхідних взводів радіоперешкод

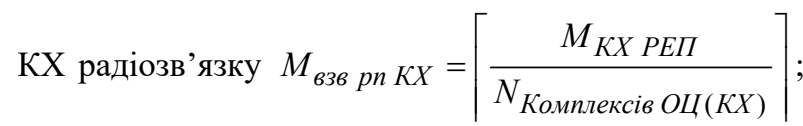
кількість необхідних взводів радіоперешкод УКХ радіозв'язку

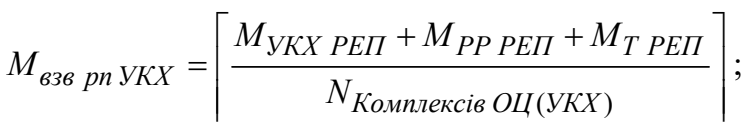

кількість необхідних взводів РЕБ 3 БпЛА $M_{\text {взв РЕБ БПЛА }}=\left\lceil\frac{M_{\text {РЕБ БПЛА }}}{N_{\text {Комплексів СЦ(БиЛА })}}\right\rceil$.

4) Аналіз отриманих результатів з метою визначення прогнозованої відповідності потрібним у даному ТБЕ спроможностей з РЕП наявних сили та засобів РЕП основних і спеціальних цілей у носія спроможностей РЕБ до обсягу та характеру завдань РЕП в операції (бойових діях).

5) Оцінювання носіїв спроможностей радіоелектронної боротьби за складовою вартості життєвого циклу в операціях (бойових діях).

Якісний і кількісний склад виробів ОВТ є основним фактором визначення персоналу (командного, оперативного, обслуговуючого тощо), потрібного формуванню - носію спроможностей для виконання бойового завдання застосування за призначенням.

Отримані для даного тактичного бойового епізоду (ТБЕ) операції (бойових дій), значення: $M_{K X}$; $M_{У K X} ; M_{T} ; M_{C K}$ дозволяють визначити якісний і кількісний склад засобів РЕБ, необхідних для набуття потрібних спроможностей з РЕП для виконання цільового (бойового) завдання військової частиною, що $€$ носієм таких спроможностей.

За отриманими (п. 3) даними щодо якісного i кількісного складу засобів РЕБ, відповідно до нормативних вимог визначається потрібна кількість персоналу (командного, оперативного, інженернотехнічного, обслуговуючого) відповідних військовооблікових спеціальностей: по комплексам $\Pi_{K X}$; $\Pi_{У К X} ; \Pi_{T} ; \Pi_{C K}-$ інженерно-технічного і оперативного; за військову частину (формування) $\Pi_{K}$;
$\Pi_{O}$ - командного і обслуговуючого.

Визначається потрібна кількість штатних підрозділів (в разі потреби позаштатних) і відповідний бойовий та чисельний склад формування.

Утримання техніки та забезпечення життедіяльності особового складу потребують відповідної логістичного забезпечення та інфраструктури.

Порядок визначення вартості військових формувань достатньо вивчено та відомо фахівцям, що проводять дослідження вартості ЖЦ військових формувань. Приклад одного 3 варіантів визначення вартості військових формувань технічної розвідки надано у [19].

Проведені дослідження показують, що у загальному випадку групуючи розрахункові витрати відповідно до елементів структури військової частини (підрозділу), отримаємо вартісні показники, які відображають необхідні витрати на вартість $\left(B_{64}\right)$ :

$$
B_{64}=B_{1}+B_{2}+B_{3}+B_{4}+B_{5}+B_{6},
$$

де $B_{1}$ - вартість придбання (розробки, виробництва) OBT;

$B_{2}$ - вартість утримання ОВТ;

$B_{3}$ - вартість утримання особового складу (персоналу);

$B_{4}$ - вартість забезпечення бойової (оперативної) підготовки особового складу;

$B_{5}$ - вартість запасів матеріально-технічних засобів (МТЗ) та вартість їх зберігання (логістичне забезпечення);

$B_{6}$ - вартість комплексу взаємопов'язаних обслуговуючих об'єктів, систем і служб (структур), що створюють умови життєдіяльності персоналу, яка не враховується у інших складових.

За умов мирного часу $B_{64}$, що розраховується на визначений період за відповідними нормативами, як правило, забезпечує спроможності військової частини в стадії “застосування” іiі життєвого циклу.

Разом $з$ тим в сучасних умовах ведення війни у гібридний спосіб і невизначеності терміну потреби iii ведення істотного значення набуває вартісна складова підготовки і виконання бойового (цільового) завдання ( $B_{B Ц 3_{64}}$ ) військовою частиною, що носієм спроможностей. При цьому, за досвідом виконання завдань силами та засобами РЕБ в період АТО та OOC, потрібно враховувати ще спроможності, які потрібні для виконання цільового завдання, у залежності від ТБЕ можуть бути забезпечені:

часткою сил та засобів від штатного бойового та чисельного складу військової частини (групами РЕБ);

повним штатним складом сил та засобів військової частини; 
3 притягненням додаткових сил та засобів до повного складу військової частини.

3 врахуванням цього, для узагальнення підходу визначимо вартість виконання бойового (цільового) завдання військовим формуванням $B_{B Ц 3_{\beta \phi}}$ як:

$$
B_{B Ц 3_{B \phi}}=\sum_{i}^{I} B_{B Ц 3_{i}},
$$

де $B_{B ц 3_{i}}$ - вартість виконання цільового завдання силами та засобами $i$-го потрібного для виконання цільового завдання класу (підкласу, типу) засобів РЕБ.

Наприклад, відповідно до прийнятого у цій роботі ТБЕ, проведених оперативно-тактичних розрахунків та аналізу результатів, можна зазначити, що протягом певного часу підготовки та виконання завдання РЕБ потребує спроможностей, що прогнозовано забезпечується військовим формуванням, які $\epsilon$ часткою сил та засобів військової частини. Тому для ТБЕ, що розглядається, вартісна складова набуття спроможностей потрібних для підготовки і виконання бойового (цільового) завдання ( $\left.B_{B Ц 3_{64}}\right)$ може бути визначена шляхом врахування таких складових:

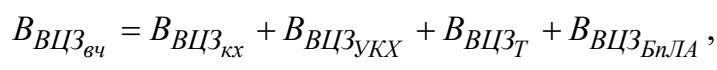

де $B_{B Ц 3_{\kappa x}}$ - вартість виконання цільового завдання силами та засобами підрозділів (комплексів, взводів, рот) РЕП КХ зв'язку;

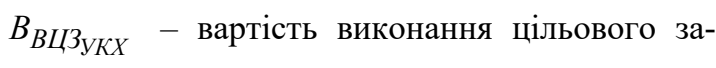
вдання силами та засобами (комплексів, взводів) РЕП УКХ зв'язку;

$B_{B Ц 3_{T}}$ - вартість виконання цільового завдання силами та засобами (комплексів, взводів) РЕП Т зв'язку;

$B_{\text {ВцЗ БилА }}$ - вартість виконання цільового завдання силами та засобами (комплексів, взводів) РЕП РЕЗ БПЛА.

У загальному випадку прогнозована вартість виконання цільового завдання - $B_{B ц 3_{в \phi}}$, розраховується по радіоелектронних засобах (РЕЗ) радіоелектронних об'єктах противника - елементарних цілях радіоелектронних впливів (РЕВ) (приймачах систем зв'язку, БпЛА, РЛС, радіокерованих вибухових пристроїв тощо). У цій роботі ми розуміємо РЕВ у широкому змісті цього поняття як необхідну послідовність заходів (електронного забезпечення, безпосередньої радіоелектронної розвідки, створення перешкод тощо), що виконується персоналом з використанням засобів РЕБ. Підготовка і проведення РЕВ потребує певних витрат, а також супроводжується певними втратами, та може бути визначає показником вартості підготовки i проведення РЕВ $B_{1 П \Pi Р в k}$. Сукупність таких РЕВ здійснюється для досягнення мети цільового застосування формування РЕБ та дозволяє оцінювати альтернативні варіанти виконання цільового завдання.

Підготовка та проведення РЕВ здійснюються в різних умовах обстановки, залежить від багатьох факторів, тому визначається певним значенням імовірності щодо виконання (успішності виконання) цільового завдання.

Вартість виконання цільового завдання формуванням РЕБ, як і досягнення мети РЕП РЕЗ противника $є$ функцією випадкової величини і носить імовірнісний характер:

$$
B_{B Ц 3}=\frac{B_{1 \Pi \Pi P B k} N_{\Sigma}}{P_{Ц 3}},
$$

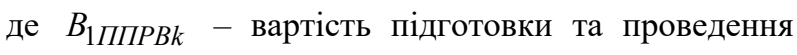
одиничного цільового застосування засобу РЕБ в k- му варіанті виконання цільового завдання;

$P_{Ц 3}$ - прогнозована імовірність виконання цільового завдання в одиничному застосуванні за цільовим призначенням;

$N_{\Sigma}$ - задана сумарна кількість елементарних цілей РЕП (радіоелектронних об'єктів), по яких прогнозується РЕВ в одиничному застосуванні за цільовим призначенням і для яких реалізується послідовний спосіб застосування засобів РЕБ.

Особливістю зразка техніки РЕБ (ЗРЕБ) є те, що вартість саме апаратури РЕБ (цільових засобів РЕБ) складає біля 25\% вартості ЗРЕБ в цілому, тому що основну iї частину складає вартість платформи, апаратури зв'язку, елементів конструкції, енергозабезпечення тощо.

Вважаємо, що різну вартість підготовки та проведення одиничного цільового застосування засобу РЕБ в $k$-му варіанті виконання цільового визначає варіант застосування зразка ОВТ, решта складові

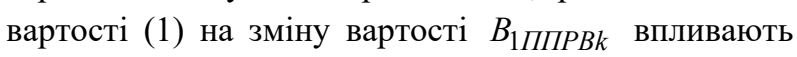
незначно.

Вартість підготовки та проведення одиничного цільового застосування засобу РЕБ в $k$-му варіанті виконання цільового завдання:

$$
B_{П П Р B_{k}}=\frac{B_{3 Р Е Б}}{N_{\text {ППРВ }}}+B_{u}+B_{\text {ВПМ }}+B_{\text {вidн }},
$$

де $B_{\text {эРЕБ }}$ - вартість нового ЗРЕБ за формулою (1);

$N_{\text {ППРв }}$ - розрахункова (гарантована з врахуванням живучості) кількість циклів підготовки та проведення РЕВ (мінімаксна по цільовим засобам PB та транспортним засобам); 
$B_{u}$ - вартість (ресурсу) цільових засобів РЕВ, використовуваних при виконанні одиничного завдання підготовки та проведення РЕВ в $k$-му варіанті цільового застосування засобу РЕБ;

$B_{B П M}$ - вартість палива і витратних матеріалів, необхідних для виконання одиничного завдання підготовки та проведення РЕВ в $k$-му варіанті цільового застосування засобу РЕБ;

$B_{\text {відн }}$ - вартість засобів, необхідних для відновлення засобу РЕБ після виконання одиничного завдання підготовки та проведення РЕВ в $k$-му варіанті цільового застосування засобу РЕБ.

Імовірність $P_{Ц 3}$ може бути визначена за вира30м:

$$
P_{Ц 3}=P_{c} \times P_{П Ш В} \times P_{3 a} \times P_{n},
$$

де $P_{c}$ - ймовірність справності засобу РЕБ впродовж одиничного цільового застосування;

$P_{\text {ПШв }}$ - ймовірність подолання противника дій, що заважають, здійсненню РЕВ (на маршруті пересування, в зоні підльоту тощо);

$P_{3 a}$ - ймовірність збереження актуальності впливу під час виконання завдання підготовки та проведення РЕВ (об'єкт не змінить свого місцеположення, режиму функціонування, не зменшиться критично його вартість і тому подібне);

$P_{n}-$ ймовірність попадання одиничної цілі PEВ впливу (РЕ3, РЕОб, площі) в просторову та частотну область РЕВ (зону дії засобу РЕБ).

Імовірність подолання шкідливого впливу (природного або штучного походження) в районі підготовки та виконання цільового завдання засобу РЕБ:

$$
P_{П \amalg в}=e^{-\sum_{i=1}^{N} \lambda_{i} t_{n i}},
$$

де $\lambda_{i}-$ інтенсивність ефективного впливу $i$-го шкідливого фактору;

$t_{n i}$ - час знаходження засобу РЕБ під дією $i$-го шкідливого фактору;

$N$ - кількість шкідливих факторів.

Ймовірність збереження актуальності (необхідності (потреби) та своєчасності) РВ впливу під час виконання завдання підготовки та проведення РЕВ розраховується за виразом:

$$
P_{3 a}=e^{-\frac{T_{\Pi \Pi P B}}{T_{o ч}}},
$$

де $T_{\text {ППРв }}$ - час виконання завдання підготовки та проведення РЕВ - сума проміжків часу від моменту отримання цільового завдання на вплив до моменту РЕВ по цілі;

$T_{\text {оч }}$ - середній час очікування - перебування цілі РЕЗ (РЕОб) противника в положенні (стані), що забезпечують умови впливу на нього засобом РЕБ.

Ймовірність попадання цілі РЕЗ (РЕОб) противника в область РЕВ (зону дії засобу РЕБ) (за умов збігу діапазонів частот засобів РЕБ та цілей РЕП, просторового розміру зони дії засобу РЕБ, що не перевищує розмір зони, по якій виконується цільове завдання за призначенням PEB на PE3 (РЕОб) противника, а також рівномірного просторового розподілу РЕЗ противника) визначається за виразом:

$$
P_{\Pi}=\frac{R(V, S, L)_{3 Р E Б}}{R(V, S, L)_{L 3}},
$$

де $R(V, S, L)_{3 Р Е Б}$ - розмір (об’єм, площа, лінійний) зони дії засобу РЕБ;

$$
R(V, S, L)_{ц 3} \text { - розмір (об'єм, площа, лінійний }
$$

розмір) зони, по якій виконується цільове завдання за призначенням РВ на РЕЗ (РЕОб) противника.

Значення наведених ймовірностей (6-9) залежать від характеристик засобів (комплексів) РЕБ, що визначаються видом, класом, підкласом і типом основних і спеціальних цілей РЕП, способами їх застосування, умовами загальної та радіоелектронної обстановки. Отримані показники (4-5) є чутливими до змін кількісного та якісного складу формування, що дозволяє оцінювати носії спроможностей РЕБ за складовою вартості ЖЦ в операціях (бойових діях) та розробляти раціональні за принципом “якість - час - вартість” варіанти застосування сил i засобів РЕБ в прогнозованих ТБЕ.

\section{Висновки}

1. Викладений підхід удосконалює оцінювання носіїв спроможностей за складовою вартості виконання ними цільового завдання за поданими показниками для визначення варіантів раціонального складу сил і засобів формування - носія спроможностей для різних бойових епізодів, що систематизує знання в предметній галузі та створює передумови для практичного застосування результатів досліджень щодо проблем сучасної збройної боротьби.

2. Запропонований математичний апарат відображає підхід до вартості життєвого циклу носія спроможностей на стадії застосування у фазі виконання цільового завдання. Отримання кількісних оцінок є окремою складною науковою проблемою, що передбачає проведення наступних досліджень та уточнення математичного апарату. 


\section{Список літератури}

1. Алімпієв А. М., Пєвцов Г. В. Особливості гібридної війни РФ проти України. Досвід, що отриманий Повітряними Силами Збройних Сил України. Наука і техніка Повітряних Сил Збройних Сил України. 2017. № 2(27). С. 19-25. https://doi.org/10.30748/nitps.2017.27.03.

2. Кожушко Я. М., Мегельбей Г. В., Резниченко А. І., Олійник Ю. А. Підвищення ролі радіоелектронної боротьби за досвідом локальних війн. Збірник наукових праџь Харківського наџіонального університету Повітряних Сил. 2012. № 3(32). С. 79-81.

3. Кожушко Я. Н., Резниченко А. И., Олейник Ю. А., Михайлик А. А. Тенденции развития авиационных средств радиоэлектронной борьбы военно-воздушных сил Соединенных Штатов Америки. Наука і техніка Повітряних Сил Збройних Сил України. 2011. № 2(6). С. 44-48.

4. Рекомендації з оборонного планування на основі спроможностей в Міністерстві оборони України та Збройних Сил України: веб-сайт. URL: https://www.mil.gov.ua/diyalnist/reformi-ta-planuvannya-u-sferioboroni/plani-ukraina2020/rekomendaczii-z-oboronnogo-planuvannya-na-osnovi-spromozhnostej-v-ministerstvi-oboroniukraini-ta-zbrojnih-silahukraini.html.

5. Методичні рекомендації з фінансово-економічного обгрунтування вартості повного життєвого циклу спроможностей з урахуванням принципів та стандартів НАТО, затверджені Міністром оборони України 02.06.2020: веб-сайт. URL: https://www.mil.gov.ua/content/oboron_plans/metod_recom_z_fin_ekon_life_ciklu_nato.pdf.

6. ДСТУ ISO/IEC/IEEE 15288:2016 Інженерія систем і програмного забезпечення. Процеси життєвого циклу систем Вид. офіц. Київ, 2018 [На заміну ДСТУ ISO/IEC 12207:2014; чинний від 2016-12-27]. Вид. офіц. Київ : УкрНДНЦ, 2018. VII, 89 с. : табл..

7. ДСТУ В-П 15.004:2019 Система розроблення і поставлення на виробництво озброєння та військової техніки. Стадії життєвого циклу озброєння та військової техніки. [Чинний від 2020-10-01 по 2023-10-01]. Вид. офіц. Київ : УкрНДНЦ, 2020. - IV, 24 с. : рис., табл.

8. NATO STANDARD AAP-20 NATO PROGRAMME MANAGEMENT FRAMEWORK (NATO Life Cycle Model) Edition C Version 1. October 2015. 78 p.

9. NATO STANDARD AAP-48:2013 NATO SYSTEM LIFE CYCLE PROCESSES. Edition B Version 1 MARS 2013. 68 p.

10. Руснак I. С., Петренко А. Г., Яковенко А.В., Романюк І. М., Кохно В. Д. Оборонне планування на основі спроможностей: особливості та перспективи впровадження. Наука і оборона. 2017. № 2. С. 3-10. https://doi.org/10.33099/26181614-2017-0-2-3-10.

11. Військовий стандарт 01.004 .002 - 2019 (02) (Видання 2) Воєнна безпека. Стратегічне планування. Терміни та визначення. Київ : МО України, 2019. 37 с.

12. Теорія озброєння. Науково-технічні проблеми та завдання. Т. 6. Воєнно-економічний аналіз життєвого изиклу озброєння та військової техніки: теоретико-методологічні засади: монографія / Чепков І. Б. та ін. Київ : ВД Дмитра Бураго, 2018. 475 c.

13. Семененко О. М., Добровольський Ю. Б., Коротя В. В., Єфименко А. Є. Методика воєнно-економічного обгрунтування доцільності рішень щодо створення, переформування, розформування підрозділів (частин) Збройних Сил України. Збірник наукових працьь Військової академії (м. Одеса). 2016. Вип. 2. С. 118-126.

14. Павловський І. В., Чепков І. Б., Борохвостов В. К., Борохвостов І. В., Рябець О. М. Науково-методичні підходи до аналізу воєнно-технічних і техніко-економічних аспектів життєвого циклу зразків озброєння та військової техніки. Наука і оборона. 2017. № 2. С 43-51. https://doi.org/10.33099/2618-1614-2017-0-2-43-51.

15. Сіренко В. Є., Демченко Є. Я. Повний життєвий цикл озброєння та військової техніки у якості критеріальної ознаки програмно-цільового планування їх розвитку. Озброєння та військова техніка. 2019. № 2(22). С. 3-15. https://doi.org/10.34169/2414-0651.2019.2(22).

16. Леонтьєв О. Б., Науменко М. В. Методичний підхід до прогнозування витрат на оновлення та використання парку озброєння та військової техніки. Військово-технічний збірник. 2021. № 24. C. 37-45. https://doi.org/10.33577/23124458.24.2021.37-45.

17. Візія Генерального штабу ЗС України щодо розвитку Збройних Сил України на найближчі 10 років. Візія Збройних Сил України. URL: https://www.mil.gov.ua/news/2020/01/11/viziyageneralnogo-shtabu-zs-ukraini-shhodo-rozvitkuzbrojnih-sil-ukraini-na-najblizhchi-10-rokiv/.

18. Пічугін М. Ф., Кожушко Я. М., Іщенко Д. А., Кирилюк В. А., Клімішен О. О. Підхід до оцінювання носіїв спроможностей радіоелектронної боротьби, необхідних для виконання завдань радіоелектронного подавлення. Наука $i$ техніка Повітряних Сил Збройних Сил Украӥни. 2021. №. 2(43). С. 31-37. https://doi.org/10.30748/nitps.2021.43.04.

19. Іщенко Д. А., Пінчук О. А., Пінчук О. І. Система показників до визначення вартості військових формувань технічної розвідки як складової їх ефективності. Проблеми створення, випробовування, застосування та експлуатації складних інформаційних систем. Технічні науки : зб. наук. пращь. 2011. Вип. 5. С. 212-219. 
Відомості про авторів:

Пічугін Михайло Федорович кандидат військових наук професор провідний науковий співробітник

Харківського Національного університету

Повітряних Сил ім. І. Кожедуба,

Харків, Україна

https://orcid.org/0000-0002-8012-7487

Кожушко Ярослав Миколайович кандидат технічних наук старший дослідник старший науковий співробітник

Харківського національного університету

Повітряних Сил ім. І. Кожедуба

Харків, Україна

https://orcid.org/0000-0002-4229-6757

\section{Іщенко Дем`ян Андрійович}

кандидат технічних наук доцент старший науковий співробітник Житомирського військового інституту ім. С.П. Корольова,

Житомир, Україна

https://orcid.org/0000-0001-9743-3889

Кирилюк Володимир Анатолійович

кандидат технічних наук

старший науковий співробітник

начальник науково-дослідної лабораторії

Житомирського військового інституту

ім. С.П. Корольова,

Житомир, Україна

https://orcid.org/0000-0003-3184-7944

Іщенко Сергій Дем'янович

старший офіцер

військова частина А0515

Київ, Україна

https://orcid.org/0000-0003-1358-1927

\section{Беспалько Олена Валеріївна}

молодший науковий співробітник

Харківського національного університету

Повітряних Сил ім. І. Кожедуба

Харків, Україна

https://orcid.org/0000-0002-5470-6450
Information about the author(s):

Mikhail Pichugin

Candidate of Military Sciences Professor

Lead Research

of Ivan Kozhedub Kharkiv National

Air Force University,

Kharkiv, Ukraine

https://orcid.org/0000-0002-8012-7487

\section{Yaroslav Kozhushko}

Candidate of Technical Sciences Senior Research

Senior Research Associate

of Ivan Kozhedub Kharkiv National

Air Force University,

Kharkiv, Ukraine

https://orcid.org/0000-0002-4229-6757

\section{Demian Ishchenko}

Candidate of Technical Sciences Associate Professor

Senior Research Associate

of S.P. Korolyov

Zhitomyr military institute,

Zhitomyr, Ukraine

https://orcid.org/0000-0001-9743-3889

\section{Volodymyr Kyryliuk}

Candidate of Technical Sciences

Senior Research

Chief of Scientific Research Laboratory

of S.P. Korolyov

Zhitomyr military institute,

Zhitomyr, Ukraine

https://orcid.org/0000-0003-3184-7944

\section{Serhii Ishchenko}

Senior Officer

of Military Unit A0515,

Kyiv, Ukraine

https://orcid.org/0000-0003-1358-1927

\section{Olena Bespalko}

Junior Research Associate

of Ivan Kozhedub Kharkiv National

Air Force University,

Kharkiv, Ukraine

https://orcid.org/0000-0002-5470-6450

\section{УСОВЕРШЕНСТВОВАНЫЙ ПОДХОД К ОЦЕНКЕ НОСИТЕЛЕЙ СПОСОБНОСТЕЙ РАДИОЭЛЕКТРОННОЙ БОРЬБЫ ПО СОСТАВЛЯЮЩЕЙ СТОИМОСТИ ЖИЗНЕННОГО ЦИКЛА}

М.Ф. Пичугин, Я.Н. Кожушко, Д.А. Ищенко, В.А. Кирилюк, С.Д. Ищенко, Е.В. Беспалько

В статье рассматриваются вопросы, связанные с разработкой элементов научно-методического аппарата оценки войск (сил) по оценке носителей возможностей радиоэлектронной борьбы по составляющей стоимости жизненного иикла. Проведен анализ литературы по данной тематике. Представлен подход к совершенствованию научнометодического аппарата оценки носителей возможностей формирований сил и средств сопроводительной поддержки путем разработки подхода к оценке носителей возможностей радиоэлектронной борьбы по составляющей стоимости их жизненного цикла в операциях (боевых действиях).

Ключевые слова: оченивание, подавление, показатель, радиоэлектронная борьба, способность. 
IMPROVED APPROACH TO ASSESSMENT OF CARRIERS OF RADIO-ELECTRONIC FIGHTING ABILITIES IN THE COMPOSITION OF LIFE CYCLE COST

M. Pichugin, Y. Kozhushko, D. Ischenko, V. Kyryliuk, S. Ischenko, O. Bespalko

The article discusses issues related to the development of elements of a scientific and methodological apparatus for assessing troops (forces) for assessing carriers of electronic warfare capabilities in terms of the life cycle cost component. The analysis of literature on this topic is carried out. It is shown that the known works do not provide a complete scientific and methodological apparatus for assessing the capabilities of such indicators that combine the cost component with the component of achieving the goal of combat use, which does not contribute to effective planning of the use of electronic warfare forces and means in the interests of combat troops (forces). An approach to improving the scientific and methodological apparatus for assessing the carriers of the capabilities of forces and accompanying support by developing an approach to assessing the carriers of electronic warfare on the component of the cost of their life cycle in operations (combat) is presented. The approach is to assess the electronic situation and expose the construction of the enemy's control (reconnaissance) system in order to establish the location, qualitative and quantitative characteristics of the enemy's electronic objects and means to determine targets, according to the combat mission of the military unit. Information about the enemy and other conditions and factors of the situation, which are lacking, identify, respectively, the typical combat episodes, which are formed in accordance with the known, based on the experience of the enemy, objects and sources of intelligence. On the basis of the position, characteristics, probable character of functioning of electronic objects and means of the enemy defined in such a way, the formation of forces and means of electronic warfare is determined, the capabilities of which ensure the performance of tasks by troops (forces). The analysis of the enemy in the formation of typical combat episodes is based on a comparison of the available factual material and the logic of the governing body's perception of the object of evaluation. The proposed mathematical apparatus reflects the approach to the cost of the life cycle of capabilities at the stage of application in the phase of the target task. Obtaining quantitative estimates is a separate complex scientific problem, which involves further research and refinement of the mathematical apparatus.

Keywords: evaluation, suppression, indicator, electronic warfare, capability. 